\title{
Effect of Temperature and Moisture on Various Aspects of Development, Growth, and Patho- genicity of Thielaviopsis paradoxa from Sugarcane in Puerto Rico ${ }^{1}$
}

\author{
Lii-Jang Liu and Amelia Cortés-Monllor ${ }^{2}$
}

\section{INTRODUCTION}

Thielaviopsis paradoxa (De Seynes) Von Höhn, the causal agent of pineapple disease of sugarcane, has been observed frequently affecting sugarcane seedpieces during the cooler months of the year in the humid areas of Puerto Rico. This same fungus, however, also has been isolated frequently from diseased seedpieces of sugarcane in the dry areas during hot summer months. Several investigators $(2,5,6)$ have provided evidence to indicate that the development of certain plant diseases is correlated closely with temperature and precipitation. In many instances, there is a certain degree of correlation between the relationship of temperature of certain fungi in pure culture to their distribution and seasonal occurrence. Kiryu (3) in 1939 in Formosa found that development of $T$. paradoxa occurred on potato sucrose agar at a temperature range of $13^{\circ}$ to $34^{\circ} \mathrm{C}$., with an optimum at $25^{\circ}$ to $31^{\circ} \mathrm{C}$. Chi (1) in 1949 also reported that the optimum temperature for the growth of the fungus occurred at $28^{\circ} \mathrm{C}$, with a range from $10^{\circ}$ to $34^{\circ} \mathrm{C}$. These investigators, however, did not report studies concerning the effect of temperature and moisture on infection of sugarcane by this fungus. Liu and Mignucci (4) in Puerto Rico reported recently on the formation of the sexual stage of $T$. paradoxa in vitro.

This investigation was conducted for the purpose of securing data showing the effect of temperature and moisture upon the growth and infectivity of several isolates of T. paradoxa in Puerto Rico, and the effect of these factors on spore germination. No previous information has been assembled concerning the effect of moisture and temperature on infection of sugarcane by this fungus. The following report thus constitutes the first concerning these factors.

\section{METHODS AND RESULTS}

\section{EFFECT OF TEMPERATURE ON SPORE GERMINATION}

Washed macro- and micro-conidial spores of $T$. paradoxa (both dark and light strains (4)) were used to inoculate water-agar plates (three for each

1 Manuscript submitted to Editorial Board August 16, 1971.

2 Phytopathologist and Assistant Bacteriologist, respectively, Agricultural Experiment Station, Mayagüez Campus, University of Puerto Rico, Río Piedras, P.R. 
temperature) which had been maintained for 1 day in precision incubators at temperatures ranging from $8^{\circ}$ to $40^{\circ} \mathrm{C}$. with $4^{\circ} \mathrm{C}$. intervals. The plates were then transferred back to the incubators at their corresponding temperatures and kept for 6, 12, and 24 hours. After each interval, counts of germinated and non-germinated spores were made with the aid of a dissecting microscope.

The results (table 1) show that the optimum range for germination of both strains of $T$. paradoxa on the medium used lies between $28^{\circ}$ and $32^{\circ} \mathrm{C}$.

\section{EFFECT OF TEMPERATURE ON MYCELIAL GROWTH}

Isolates of both strains of $T$. paradoxa from sugarcane were grown in potato dextrose agar medium at the following nine temperatures: $8^{\circ}, 12^{\circ}$,

\section{TABLE 1.-Effect of temperature on spore germination of Thielaviopsis paradoxa} (both light and dark strains) from sugarcane ${ }^{1}$

\begin{tabular}{|c|c|c|c|c|c|c|c|c|}
\hline \multirow{4}{*}{$\begin{array}{l}\text { Temper- } \\
\text { ature }\end{array}$} & \multicolumn{4}{|c|}{ Light strain $\left(T_{1}\right)$} & \multicolumn{4}{|c|}{ Dark strain $\left(T_{2}\right)$} \\
\hline & \multicolumn{2}{|c|}{ Microspore } & \multicolumn{2}{|c|}{ Macrospore } & \multicolumn{2}{|c|}{ Microspore } & \multicolumn{2}{|c|}{ Macrospore } \\
\hline & \multicolumn{4}{|c|}{ Spore germination at the end of- } & \multicolumn{4}{|c|}{ Spore germination at the end of- } \\
\hline & 6 hours & 12 hours & 12 hours & 24 hours & 6 hours & 12 hours & 12 hours & 24 hours \\
\hline${ }^{\circ} \mathrm{C}$. & Percent & Percent & Percent & Percent & Pereent & Percent & Percent & Percent \\
\hline 8 & $\mathbf{0}$ & 0 & 0 & 0 & 0 & $\mathbf{0}$ & 0 & $\mathbf{0}$ \\
\hline 12 & 0 & 0 & 0 & 42 & 21 & 20 & 11 & 22 \\
\hline 16 & 23 & 32 & 21 & 42 & 42 & 61 & 22 & 40 \\
\hline 20 & 34 & 76 & 18 & 33 & 43 & 81 & 24 & 40 \\
\hline 24 & 26 & 66 & 19 & 34 & 64 & 82 & 25 & 43 \\
\hline 28 & 42 & 87 & 22 & 42 & 66 & 84 & 36 & 66 \\
\hline 32 & 63 & 74 & 33 & 65 & 87 & 74 & 44 & 86 \\
\hline 36 & 48 & 68 & 24 & 48 & 43 & 61 & 21 & 42 \\
\hline 40 & 0 & 0 & 10 & 20 & 0 & 0 & 0 & 0 \\
\hline
\end{tabular}

${ }^{1}$ Average of 3 replications.

$16^{\circ}, 20^{\circ}, 24^{\circ}, 28^{\circ}, 32^{\circ}, 36^{\circ}$, and $40^{\circ} \mathrm{C}$. For each temperature, five petri dishes containing $15 \mathrm{ml}$. of the above-mentioned medium were separately inoculated with small, uniform, round discs of mycelium $(2 \mathrm{~mm}$. in diameter) of both strains. The discs were cut with a sterile cork borer from the advancing margin of colonies kept in potato dextrose agar. The dishes containing the inoculum were incubated in the precision incubators at the different temperatures for 2 days. The increase in the diameter of colonies was measured at the end of the incubation period.

The optimum temperature range for mycelial growth of both strains was found to be above $28^{\circ} \mathrm{C}$, with the maximum $36^{\circ} \mathrm{C}$. and the minimum below $12^{\circ} \mathrm{C}$. No mycelial growth was obtained either at $8^{\circ}$ or at $40^{\circ} \mathrm{C}$. (fig. 1). 


\section{EFFECT OF TEMPERATURE ON INFECTION}

The cut ends of single-eyed seedpieces of sugarcane variety P.R. 980 were separately inoculated with small, uniform, round discs of mycelium $(2 \mathrm{~mm}$. in diameter) of the light strain $\left(T_{1}\right)$ of $T$. paradoxa from sugarcane. The inoculated seedpieces were planted in enamelled trays containing sterilized sand and incubated in precision incubators for 7 days at the following temperatures: $8^{\circ}, 12^{\circ}, 16^{\circ}, 20^{\circ}, 24^{\circ}, 28^{\circ}, 32^{\circ}$, and $40^{\circ} \mathrm{C}$. At the end of the in-

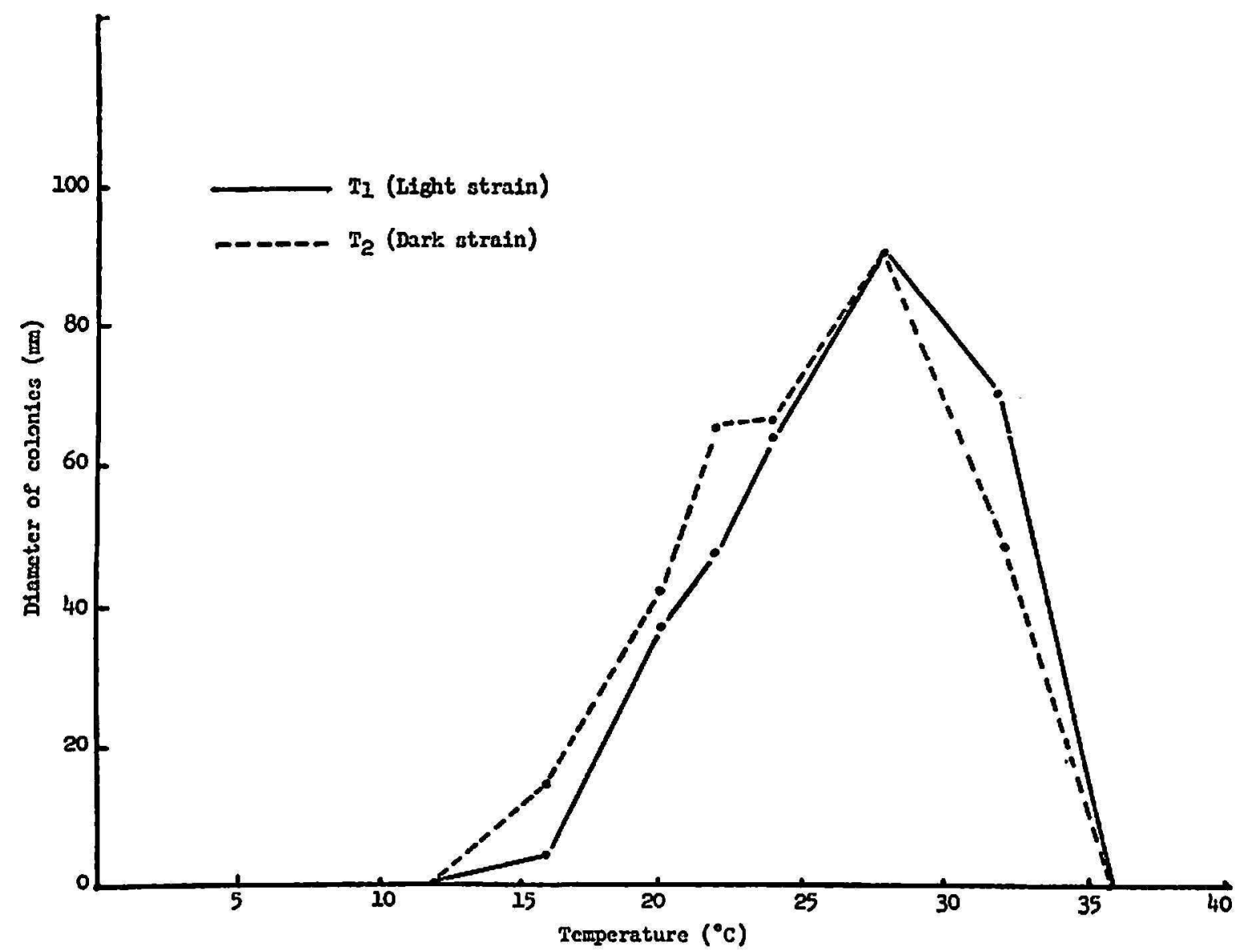

Fig. 1.-Diameter of colonies of Thielaviopsis paradoxa on potato dextrose agar at different temperatures.

cubation period, the length of the discolored (infected) areas of the sugarcane seedpieces was measured.

The results (fig. 2 and 3) show that the highest rate of infection of sugarcane seedpieces by $T$. paradoxa (light strain) occurred between $28^{\circ}$ to $32^{\circ} \mathrm{C}$. when inoculated seedpieces were incubated for 7 days at the above-mentioned temperatures. No infection of sugarcane by T. paradoxa was obtained at temperatures higher than $36^{\circ} \mathrm{C}$. or lower than $8^{\circ} \mathrm{C}$.

\section{FFFECT OF MOISTURE ON INFECTION}

The cut ends of single-eyed seedpieces of P.R. 1059 were separately inoculated with small, uniform, round discs of mycelium $(2 \mathrm{~mm}$. in diame- 
ter) of the dark strain $\left(T_{2}\right)$ of $T$. paradoxa from sugarcane. The inoculated seedpieces were planted in enamelled trays containing sterilized sand with the following moisture content: $75,50,25,12.5,6.25$, and 0 percent. $^{3}$ The trays were then maintained in precision incubators for 10 days at the following temperatures: $22^{\circ}, 28^{\circ}, 32^{\circ}$, and $36^{\circ} \mathrm{C}$. For each moisture content, three trays (each containing five inoculated seedpieces of sugarcane) were maintained at each of the above-mentioned temperatures. After incubation the length of the infected areas was measured.

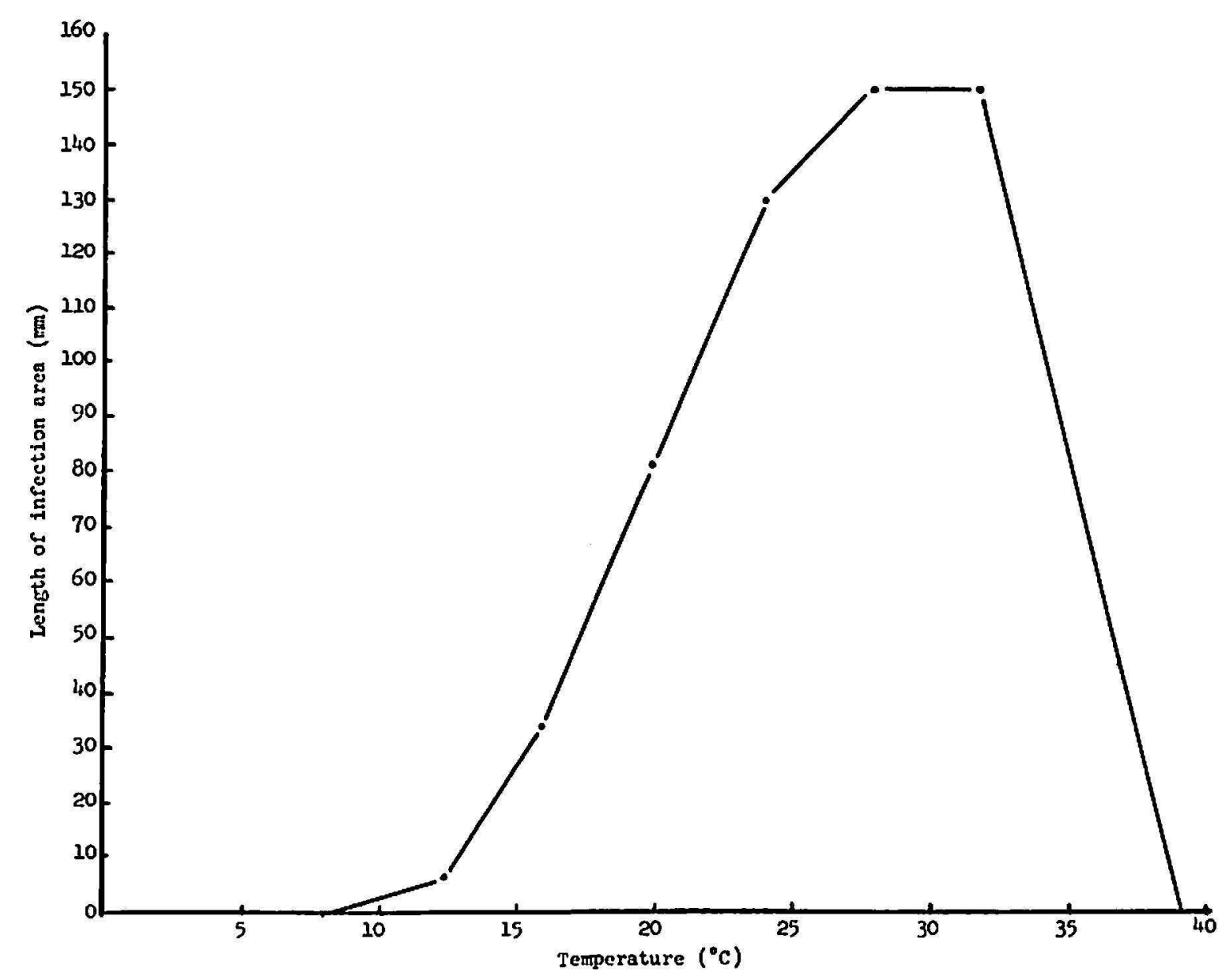

Fig. 2.-Effect of various temperatures on infection of sugarcane seedpieces by Thielaviopsis paraloxa.

The results (table 2 and fig 4 ) show that the highest rate of infection of sugarcane seedpicces by $T$. paradoxa (dark strain) occurred at 0-percent moisture content of the soils when incubated at temperatures of $22^{\circ}, 28^{\circ}$, and $32^{\circ} \mathrm{C}$. However, this same result was not obtained when the inoculated

${ }^{3} 0$-percent moisture content means that sands were dried to 0 percent and no water was added; the moisture content of the seedpieces was determined at approximately 76.6 percent; and the air relative humidity during the period of the experiment ranged from 60 to 70 percent. 


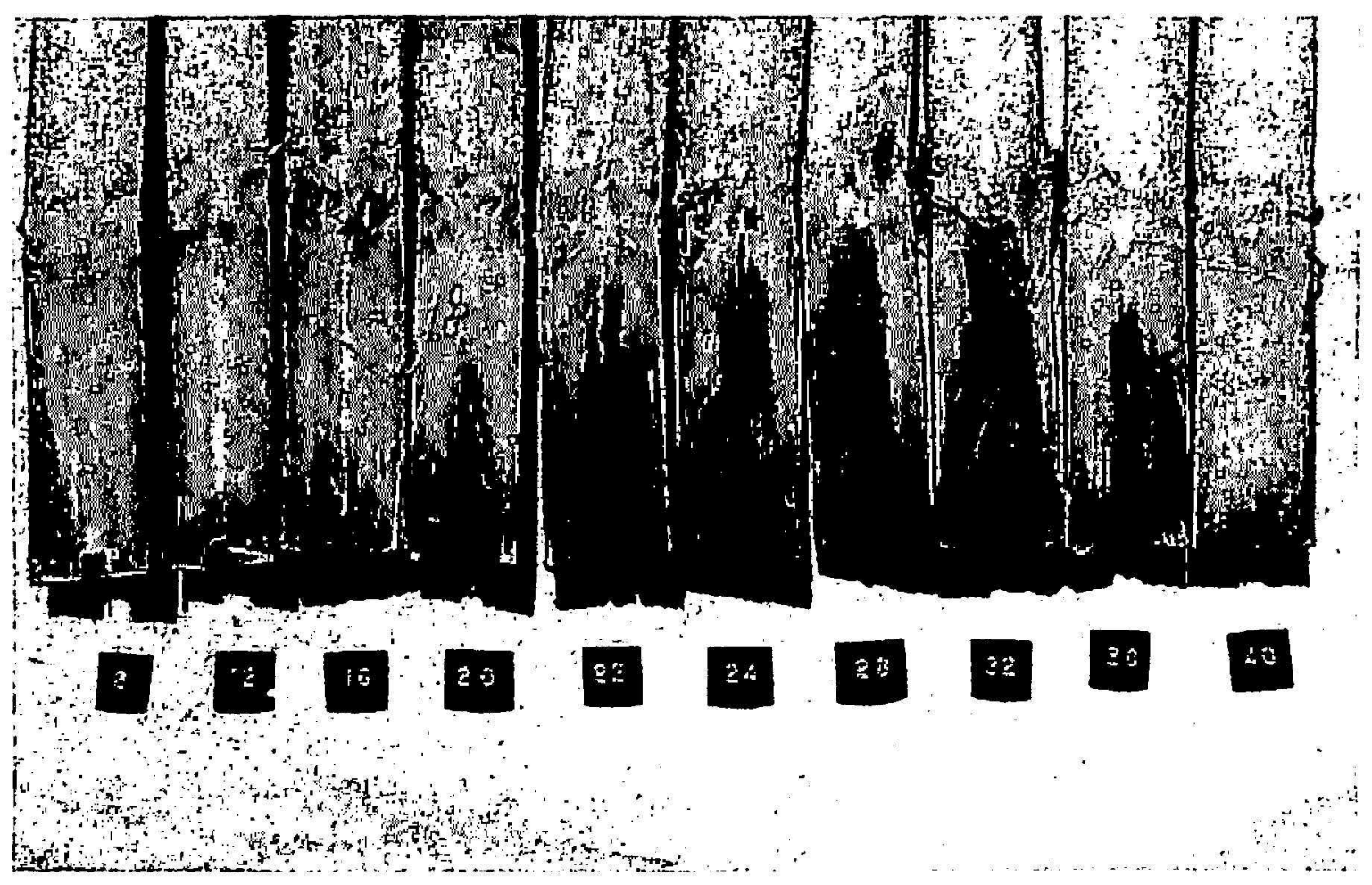

FIg. 3.-Differences in rate of infection of sugarcane seedpieces of sugarcane variety P.IR. 980 by Thielaviopsis paradoxa at various temperatures; from left to right, $8^{\circ}, 16^{\circ}, 20^{\circ}, 22^{\circ}, 24^{\circ}, 28^{\circ}, 32^{\circ}, 36^{\circ}$, and $40^{\circ} \mathrm{C}$., respectively.

secdpieces were incubated at $36^{\circ} \mathrm{C}$. The highest rate of secdpieces infection at $36^{\circ} \mathrm{C}$. occurred between 25- to 50-percent moisture content of the soils.

A study of the correlation coefficient between moisture content of the soil and length of infection area of sugarcane seedpieces by $T$. paradoxa revealed that the regression cocfficients $(r)$ at temperatures of $22^{\circ}, 28^{\circ}$, and $32^{\circ} \mathrm{C}$. were negative, while positive at $36^{\circ}$. Table 3 shows the functional relationship worked out and gives the cocfficient of correlation. The $F$ value was highly significant for the above-mentioned temperatures, and significant for $36^{\circ} \mathrm{C}$. This suggests that there is an interaction between the

TABLE 2.-Differences in length of infection arcas (expressed in inches) in sugarcane seedpieces by Thielaviopsis paradoxa at varicus levels of soil moisture content

\begin{tabular}{|c|c|c|c|c|c|c|c|}
\hline & \multirow{2}{*}{\multicolumn{2}{|c|}{ Treatment }} & \multirow{2}{*}{$\begin{array}{c}\text { Moisture } \\
\text { content }\end{array}$} & \multicolumn{4}{|c|}{ Incubated at- } \\
\hline & & & & $22^{\circ} \mathrm{C}$ & $28^{\circ} \mathrm{C}$ & $32^{\circ} \mathrm{C}$ & $36^{\circ} \mathrm{C}$ \\
\hline & \multicolumn{7}{|c|}{ Percent } \\
\hline A & 0 water & & 0 & 1.71 & 2.14 & 3.50 & 0.14 \\
\hline B & Added & $125 \mathrm{ml}$. waler & 6.25 & 1.29 & 1.59 & 2.84 & .29 \\
\hline $\mathrm{C}$ & do. & $250 \mathrm{ml}$. do. & 12.5 & 1.12 & 1.30 & 2.86 & .51 \\
\hline $\mathrm{D}$ & do. & $500 \mathrm{ml}$. & 25 & .84 & .62 & 2.56 & 1.54 \\
\hline li: & do. & $1,000 \mathrm{ml}$. do. & 50 & .70 & .26 & 2.44 & 1.68 \\
\hline $\mathbf{F}$ & do. & $1,500 \mathrm{ml}$. do. & 75 & .00 & .00 & 1.60 & 1.47 \\
\hline
\end{tabular}




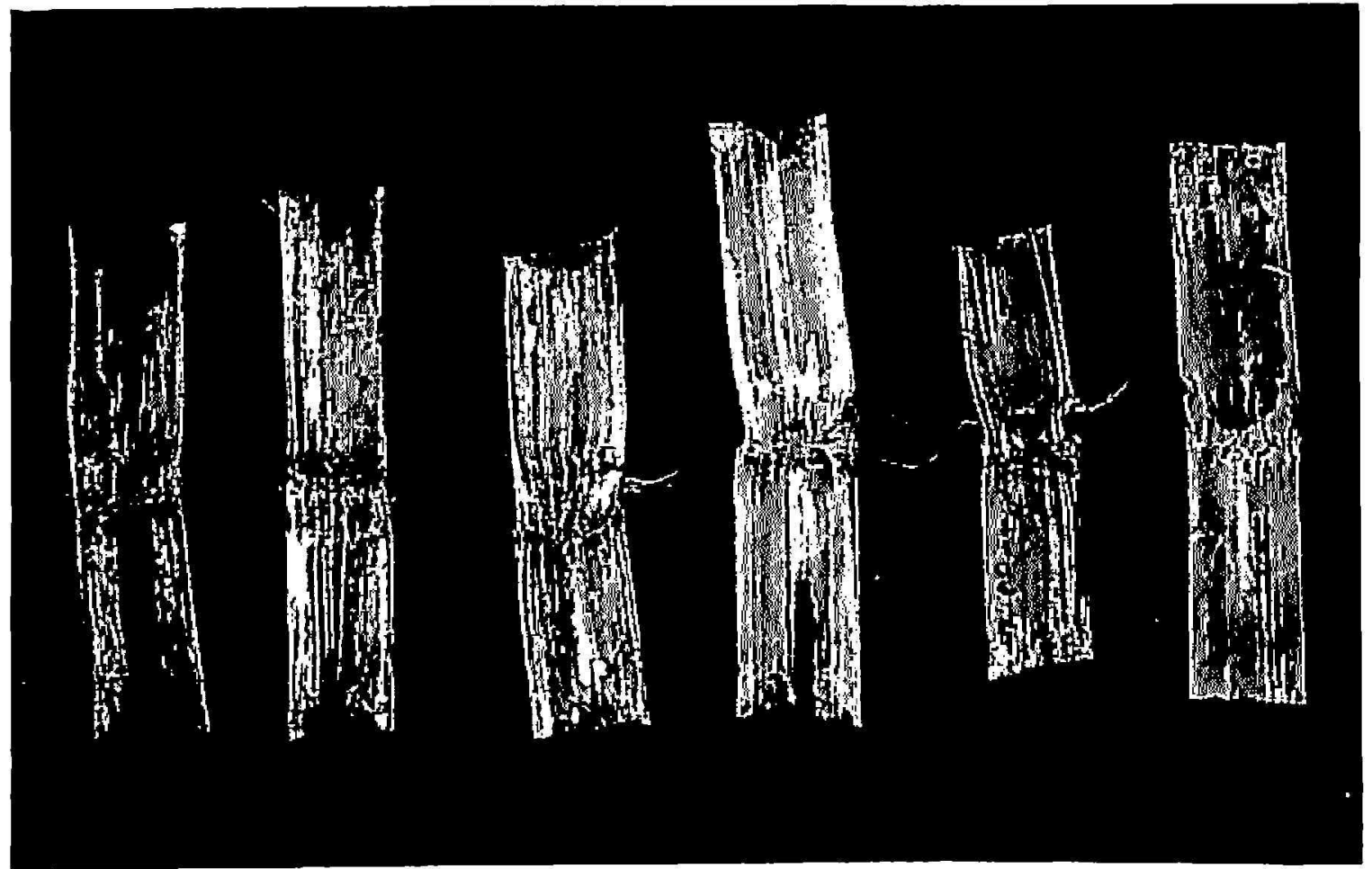

Fig. 4.-Rate of infection of sugarcane seedpieces of P.R. 1059 by Thielaviopsis paradoxa at $28^{\circ} \mathrm{C}$. under various levels of soil moisture content; from left to right, 0 , $6.25,12.5,25,50$, and 75 percent, respectively.

influenes of temperature and soil moisture on the rate of infection of sugarcane seedpieces by $T$. paradoxa, there being a decrease of infection with soil moisture at 22 and $32^{\circ} \mathrm{C}$, and an increase of infection with soil moisture at $36^{\circ} \mathrm{C}$.

\section{EFFECT OF TEMPERATURE AND MOISTURE ON DISTRIBUTION AND SEASONAL OCCURIRENCE}

A number of surveys were made to record the incidence of pineapple disease of sugarcane at various times in different areas of Puerto Rico.

TABLE 3. Soil moisture content in relation to degree of infection of sugarcane seedpieces by Thielaviopsis paradoxa

\begin{tabular}{ccccc}
\hline Temperature & Functional relationship' & Correlation coeficient $(r)$ & F-value \\
\hline${ }^{\circ} \mathrm{C}$. & & & & \\
22 & $Y=1.4868-0.0193 X$ & -0.9604 & $47.61^{* *}$ \\
28 & $Y=1.7319-.0266 X$ & -.9295 & $25.42^{* *}$ \\
32 & $Y=3.2018-.0202 X$ & -.0365 & $28.56^{* *}$ \\
36 & $Y=.3851+.0197 X$ & .8166 & $8.00^{*}$ \\
\hline
\end{tabular}

${ }^{1} Y=$ Average length of infection areas of sugarcane seedpieces to be estimated (inches); $X=$ soil moisture content ( $\mathrm{ml}$. in $2000 \mathrm{~g}$. of soil).

$2^{*}=$ Regression is significant at 5 -percent level; ${ }^{* *}=$ regression is highly significant at 1 -percent level. 
$\mathrm{T}_{A \mathrm{BLE}}$ 4.- Relation of temperature and rainfall to distribution and seasonal occurrence of pineapple disease of sugarcane in Puerto Rico

\begin{tabular}{|c|c|c|c|c|}
\hline Ecological zones & Locality & Variety & Extent of pineapple disease observed & Season observed \\
\hline $\begin{array}{l}\text { 1. Low temperature zone-with average } \\
\text { temperature } 71^{\circ} \mathrm{F} \text {. during January } \\
\text { to March and } 76^{\circ}-77^{\circ} \mathrm{F} \text {. during June } \\
\text { to August. }\end{array}$ & $\begin{array}{l}\text { Central Cambalache } \\
\text { Central Roig } \\
\text { Central Monserrate } \\
\text { Central Coloso }\end{array}$ & $\begin{array}{l}\text { B. } 49119 \\
\text { H. } 32-8560 \\
\text { P.R. } 980 \\
\text { B. } 4362 \\
\text { B. } 49119 \\
\text { H. } 32-8560\end{array}$ & $\begin{array}{c}\text { Widespread } \\
\text { do. } \\
\text { Occasionally observed } \\
\text { do. } \\
\text { do. } \\
\text { do. }\end{array}$ & $\begin{array}{c}\text { Winter, } 1969 \\
\text { do. } \\
\text { Spring, } 1970 \\
\text { do. } \\
\text { do. } \\
\text { do. }\end{array}$ \\
\hline $\begin{array}{l}\text { 2. Moderate temperature zone-with } \\
\text { average temperature } 72^{\circ}-75^{\circ} \mathrm{F} \text {. dur- } \\
\text { ing January to March and } 78^{\circ}-79^{\circ} \mathrm{F} \text {. } \\
\text { during June to August. }\end{array}$ & $\begin{array}{l}\text { Central Igualdad } \\
\text { San Sebastián }\end{array}$ & $\begin{array}{l}\text { B. } 49119 \\
\text { H. } 32-8560\end{array}$ & $\begin{array}{l}\text { do. } \\
\text { do. }\end{array}$ & $\begin{array}{c}\text { Autumn, } 1970 \\
\text { do. }\end{array}$ \\
\hline $\begin{array}{l}\text { 3. High temperature zone-with aver- } \\
\text { age temperature } 76^{\circ}-79^{\circ} \mathrm{F} \text {. during } \\
\text { January to March and } 82^{\circ}-83^{\circ} \mathrm{F} \text {. } \\
\text { during June to August. }\end{array}$ & $\begin{array}{l}\text { Central Mercedita } \\
\text { Central Guánica }\end{array}$ & $\begin{array}{l}\text { B. } 49119 \\
\text { B. } 49119\end{array}$ & $\begin{array}{l}\text { Widespread } \\
\text { do. }\end{array}$ & $\begin{array}{c}\text { Summer, } 1970 \\
\text { do. }\end{array}$ \\
\hline
\end{tabular}


Pineapple disease of sugarcane was found to be widespread (table 4) on B. 49119 and H. 32-8560 at Central Cambalache and Central Roig in wintor, when the average temperature ranged from $63^{\circ}$ to $78^{\circ} \mathrm{F}$. $\left(17^{\circ}-26^{\circ} \mathrm{C}\right.$.). At Central Guánica and Mercedita, it was also found to be widespread on B. 49119 in the summer when the average temperature ranged from $82^{\circ}$ to $83^{\circ}$ F. $\left(27^{\mathrm{C}}-28^{\circ} \mathrm{C}\right.$. $)$.

\section{DISCUSSION}

The results obtained in this study agree generally with those of Kiryu (3) and Chi (1) in Taiwan, who found the optimum temperature for mycelial growth and spore germination of $T$. paradoxa from sugarcane to be between $28^{\circ}$ and $32^{\circ} \mathrm{C}$. The highest degree of infection of sugarcane secdpices by this fungus also occurred within this temperature range.

It is interesting to note that high moisture content of the soil (50 to 75 percent) did not increase infection of sugarcane by this fungus when inoculated seedpieces were incubated at temperatures of $22^{\circ}$ to $32^{\circ} \mathrm{C}$. The highest rate of infection of sugarcane seedpieces by $T$. paradoxa occurred at the lowest moisture content of the soil (0 percent).

In the northern and western part of Puerto Rico, temperatures during the winter months range from $71^{\circ}$ to $75^{\mathrm{c}} \mathrm{F}$. $\left(22^{\circ}\right.$ to $24^{\circ} \mathrm{C}$.). These temperatures are not the most favorable for infection of sugarcane by $T$. paradoxa. Low rainfall during this period, however, may contribute to severe infection of sugarcane seedpieces by this organism.

In the southern part of Puerto Rico (Central Mercedita area) temperatures during the summer months range from $82^{\circ}$ to $83^{\circ} \mathrm{F}$. $\left(22^{\circ}\right.$ to $28^{\circ} \mathrm{C}$.). These temperatures are ideal for infection of sugarcane by $T$. paradoxa. Drought during this period tends to aggravate the situation.

\section{SUMMARY}

It was found that the optimum temperature range for mycelial growth and spore germination of Thielaviopsis paradoxa lies between $28^{\circ}$ and $32^{\circ}$ C., with the maximum above $36^{\circ} \mathrm{C}$. and the minimum below $12^{\circ} \mathrm{C}$. Neither mycelial growth nor spore germination was obtained at $8^{\circ}$ or at $40^{\circ} \mathrm{C}$.

Pathogenicity of T. paradoxa to sugarcane variety P.R. 1059 was favored by temperatures between $28^{\circ}$ and $32^{\circ} \mathrm{C}$. No infection of sugarcane by this fungus occurred at $8^{\circ}$ or at $40^{\circ} \mathrm{C}$.

The highest rate of infection of sugarcane by $T$. paradoxa was obtained at the lowest soil moisture with a maximum temperature up to $32^{\circ} \mathrm{C}$. It thus appears that low soil moisture has a profound effect on rate of infection during summer months in Puerto Rico.

\section{RESUMEN}

Se determinó que la temperatura óptima para el crecimiento del micelio y la germinación de las esporas de Thielaviopsis paradoxa fuctúa entre $20^{\circ}$ y $32^{\circ} \mathrm{C}$., siendo el 
nivel máximo mayor de $38^{\circ} \mathrm{C}$ y el mínimo menor de $12^{\circ} \mathrm{C}$. No se logró que el micelio creciera ni que las esporas germinaran a los niveles de $8^{\circ}$ y $40^{\circ} \mathrm{C}$.

Las temperaturas de $28^{\circ}$ a $32^{\circ} \mathrm{C}$. propiciaron la patogenicidad de $T$. paradoxa en la variedad de caña de azúcar P.R. 1059, pero no se logró la infección de la caña por el hongo a los niveles de $8^{\circ}$ y $40^{\circ} \mathrm{C}$.

El grado de infección de la caña por $T$. paradoxa fue mayor cuando más bajo era el contenido de humedad en el suelo hasta una temperatura máxima de $32^{\circ} \mathrm{C}$. Tal parece, por tanto, que un bajo contenido de humedad en el suelo afecta marcadamente el grado de infección durante los meses del verano en Puerto Rico.

\section{LITERATURE CITED}

1. Chi, C. C., A preliminary report on the study of pineapple disease of sugarcane in Taiwan, J. Sugarcane Res. 3: 71-102, 1949.

2. Edson, H. A., and Shapovalov, M., Temperature relations of certain potato rot and wilt producing fungi, J. Agr. Res. 18: 511-24, 1920.

3. Kiryu, T., Studies on the physiological characters of Ceralostomella paradoxa, Rept. Govt. Sugar Expt. Sta., Taiwan, 6: 21-37, 1939.

4. Liu, L. J., and Mignucci, J., In vitro formation of sexual stage of Thielaviopsis paradoxa from sugarcane in Puerto Rico, J. Agr. Univ. P.R. 55 (1): 94-100, 1971.

5. Rosembraum, J., and Ramsey, G. B., Influence of temperature and precipitation on the blackleg of potato, J. Agr. Res. 13:507-13, 1918.

6. Stevens, N. E., The influence of temperature on the growth of Endothia parasitica, Am. J. Botan. $4: 112-8,1917$. 